\title{
Spor Aristotela s Platónem o výchovnou funkci tragického divadla ${ }^{\mathrm{i}}$
}

\section{Jaroslav Daneš}

\section{Úvod}

Instituce divadelních představení měla $\mathrm{v}$ Athénách klasického období mimořádný politický význam, což je patrné jak z děl současníků, tak z prací moderních badatelů. ii Organizace a provozování divadla bylo veřejnou činností spojenou se stáním aparátem demokratických Athén po formální i obsahové stránce. Luciano Canforaiii hovoří o divadle jako o jednom ze trrí pilírư demokratické obce. Jak autoři divadelních kusů, tak politikové (obě kategorie lze těžko odlišit) pohlíželi na divadlo jako na

\footnotetext{
i Článek vznikl v rámci grantového projektu GAČR 401/09/P032 Řecká tragická poezie a politické myšlení. Poprvé byl publikován anglicky pod názvem Aristotle versus Plato on Tragedy with Respect to Civic Education. In: Anthology of Philosophical Studies IV. Athens 2010, pp. 7-19. Současná verze má rozšířený poznámkový aparát, odkazy na literaturu a úprav doznala část o Aristotelovi. Článek věnuji památce kolegy doc. Milana Mráze.

ii Mám na mysli především Velké Dionýsie. Ísokratés, De pace 82; Démosthenés, De corona 120; S. Goldhill (2000: 60-65), Tentýž, (1990: 97129), Ch. Meier 1993: 44-51).

iii L. Canfora (1994:124)
} 
prostředek výchovy občanů. ${ }^{i}$ Není proto překvapivé, že Platón a Aristotelés jako nejoriginálnější postavy aristokratického disentu ${ }^{\mathrm{ii}}$ a bystří kritikové fungování athénské demokracie věnovali náležitou pozornost i dramatické básnické tvorbě jako jedné z nejvýznamnějších institucí demokratických Athén. $\mathrm{V}$ tomto článku bych rád odpověděl na otázku, zda je dle Platóna a Aristotela možné či žádoucí vychovávat občany prostřednictvím tragického divadla.

\section{a) Platón a tragédie}

Největší prostor diskusi o roli tragické poezie ve společnosti v rámci diskuse o úloze básnické tvorby věnuje Platón ve třech politických dialozích Gorgias, Politeia a Zákony. Ve všech třech dílech je jeho pohled na tragickou poezii odmítavě kritický. Platónova kritika vychází z epistemologicko-psychologických úvah, které mají podpořit jeho tezi o nedostatečnosti demokratického vědění a chybnosti fungování demokratických institucí. Abychom tedy pochopili kritiku tragické poezie, musíme nejprve stručně nastínit Platónovu kritiku demokracie, která vychází z kritické analýzy demokratických hodnot a výchovy.

\footnotetext{
i Aristofanés, Žáby 1054-1055; Acharňané 496-509; Oblaky.

ii Přebírám termín Josiaha Obera (1998)
} 
Základním předpokladem Platónovy analýzy je teze, že mravy ve společnosti jsou průmětem mravů jednotlivých členů (Rep. 435c). V duši každého jednotlivce jsou obsaženy tři druhy: rozum, vznětlivost a žádostivost. Složkou rozumnou poznáváme, složka žádostivá zabezpečuje, že si opatřujeme věci potřebné pro život, a složka vznětlivá má na svědomí emoční roznícení (vztek). V každém člověku je největší částí duše složka žádostivá, jejíž hypertrofie ohrožuje jak duši, tak společnost. Zbylé dvě části duše ji tedy musí hlídat, přičemž svrchovaným vládcem má být rozum (Rep. 442a). Protože žádostivost má mnoho podob, rozlišuje Sókratés žádosti nutné a nenutné (Rep. 558d-559d). Žádosti nutné se moderně řečeno kryjí s existenčními potřebami. Sókratés o nich hovoří jako o nutných žádostech, jichž není možné se zbavit a jako o žádostech, které jsou člověku ku prospěchu, jsou-li naplňovány. Jako prŕiklad je možné uvést stravu. Nutnou žádostí je se najíst, nenutnou přejídat se. Když Sókratés líčí proměnu člověka oligarchie v člověka demokracie, popisuje tyto nenutné žádosti jako sílu, která osadí velitelství duše mladého muže, v němž byly oslabeny nebo vytlačeny ušlechtilé zásady a řádné vzdělání. Tyto žádosti pak vyženou $z$ duše stud, rozumnost a skromnost (560b-d).

\footnotetext{
i O úskalí a nesprávnosti analogií vedených mezi jednotlivcem a obcí pojednává M. Schofield (2006:268-269)
} 
Tento proces je podpořen opilostí ze svobody. Platón charakterizuje demokracii jako zř́zení extrémně oddané svobodě a rovnosti. Pojetí svobody v demokratické obci Sókratés podobně jako Periklés $v$ Pohřební řeči ${ }^{i}$ charakterizuje výrazem žít, jak se komu zlíbí. Ovšem zatímco Periklés $\mathrm{v}$ uvedené řeči hovoří o limitech svobodného počínání (zákony, nepsaná pravidla apod.), tak Sókratés v Politeii toto pojetí svobody karikuje a hovoří o něm jako o čisté libovůli. S ohledem na pojetí duše a tezi, že politika je průmětem individuálních duší, hodnotí Platón demokratické pojetí svobody a výchovy jako rizikové nebo nebezpečné, protože nepodporuje kultivaci žádostivé složky duše a nadvládu rozumu. Toto pojetí svobody dle Platóna obsahuje destruktivní dynamiku, jejímž vyústěním mohou být anarchie nebo tyranida ${ }^{\text {ii }}$. Dle Platóna je člověk, který dělá to, co se mu zlíbí, podoben tyranovi, protože tyrana charakterizuje čistá libovůle, ve skutečnosti je však otrokem, který otročí svým žádostem. ${ }^{\text {iii }}$ Tento iracionální sklon, který považuje moc za podmínku štěstí, je dle Platóna snem každého člověka (Leg. 687c). Ubránit se mu je možné jen za pomoci výuky a vzdělání, která má očistné

\footnotetext{
i Thuk. 2.37

ii Srov. M. Schofield (2006:107-112 a 117-121).

iii Srovnej závěr dialogu Alkibiadés (135a-e). Přestože o pravosti dialogu Alkibiadés se vedou spory, názory $\mathrm{v}$ něm obsažené jsou zřetelně platónské.
} 
účinky. Zásady této výchovy jsou nejhutněji vyjádřeny v dialogu Sofistés (227d-229c), kde je náležitá výchova označena jako očišt'ovací (katartická)i. Host z Eleje podrobně vysvětluje od čeho je třeba duši očišt'ovat, jak rozumět očišt'ování a jak jej provádět. Duši je třeba zbavovat všeho, co je různé od ctnosti a to je nazýváno zlem. Zlo je dvojího druhu. Jednak je špatností, kterou Host z Eleje definuje jako nesoulad v duši a obecný nedostatek míry, jednak je nevědomostí. Zatímco prvním druhem se zabývá právo, druhý se snaží odstranit katartická výchova spočívající velenchu (analytické myšlení a dokazování). Elenchos slouží k odstranění nepravdivých mínění a ke vzbuzení studu pocházejícího z uvědomění si vlastní nevědomosti. Je to tedy filosofie neboli nejvznešenější druh rétoriky, která je podstatou katartické výchovy.

Tragická a komická poezie je pro Platóna nápodobou $(\mu i ́ \mu \eta \sigma ı)^{\mathrm{ii}}$ povah při rozmanitých činnostech. Platónovo hodnocení napodobování je však komplikované. Obecně by se dalo říct, že na poli epistemologie napodobování zcela zavrhuje. Avšak voblasti pedagogiky rozlišuje mezi dobrým a špatným napodobováním. Proč zavrhuje napodobování? Napodobování není ex definitio poznávání.

\footnotetext{
i S. Salkever (1990) podává ve svém článku stručný souhrn významů výrazu katharsis u Platóna sodkazem na obsáhlejší pojednání Lain Entralgo, Therapy of the Word, str. 127-138.

ii Rep. 394b-c ; Leg. 655e, 817b.
} 
V 10. knize Politeii (601c-602b) je užito př́kladu s výrobou uzdy a flétny a Sókratés hodnotí vědění výrobce, uživatele a napodobitele. Dle jeho názoru uživatel flétny má dokonalou zkušenost s výrobkem a informuje výrobce, co je dobré nebo špatné na jeho výrobku. Zhotovitel flétny bude důvěřovat uživateli a zařídí se podle toho. Avšak napodobitel flétny nebude mít ani vědění o flétně, zda je udělána správně, ani správné mínění o napodobovaných předmětech vzhledem $k$ jejich kráse. Pokud se však bude jeho napodobování líbit mnoha lidem, bude dále napodobovat flétnu bez její znalosti. Napodobování je tedy jakousi hrou, a nikoli vážně míněnou poznávací aktivitou s nárokem na pravdivost. Napodobování a jeho různé druhy (maliřství, básnictví) jsou uměními iluze a nedotýkají se reality a pravdy. Jsou dokonce až na třetím místě od pravdy (Rep. 602c) $)^{\mathrm{i}}$ Pravdu je možné nahlédnout pouze prostřednictvím dialektiky, která je oporou rozumné části duše (Rep. 532a-534e). Na druhou stranu, když Sókratés probírá možnost založit stát, ve kterém vládnou filosofové, hovoří o něm jako o nápodobě božského vzoru a přirovnává filosofy k malířům (Rep. 501b). Rovněž v Zákonech Athénský host odpovídá cizinci na otázku, zda mají cizinci do jejich země přinášet dramatickou tvorbu, poukazem na to, že oni sami jsou tvůrci nejkrásnější a nejlepší tragédie,

i Viz 597b-e. 
protože jejich ústava je nápodobou nejkrásnějšího a nejlepšího života - života bohů (817b). ${ }^{\mathrm{i}}$

Platón tedy není důsledný v zavrhování napodobování a rozlišuje mezi dobrým a špatným napodobováním. ${ }^{\text {ii }}$ Toto rozlišení je provedeno jak v Politeii, tak v Zákonech Jak ale definuje dobré a špatné napodobování? V Politeii hovoří o špatném a dobrém napodobování v souvislosti s múzickým vzděláním strážců. Když Sókratés dokončil výklad o tom, jak se má mluvit o bozích, daimónech a hrdinech (379a392c), přechází k pojednání o lidech a vhodnosti slovesných druhů. Strážci, jejichž úkolem je dokonale rozvinout svou osobnost, se proto nemají zabývat běžnými zaměstnáními a nápodobou. Pokud už mají něco napodobovat, pak jen to, co se vztahuje k jejich činnosti: svobodné počínání, rozumnost, uměřenost, zbožnost apod. (395c). Naopak se mají vystříhat napodobování srdceryvných a emočně přepjatých projevů, at' už jde o radost nebo smutek apod. Jinými slovy napodobování jednání, které je považováno za dobré, je možné kvalifikovat jako jednání urozeného člověka, jenž je

\footnotetext{
${ }^{i}$ Na základě těchto úvah je třeba konstatovat, že i Platónovy dialogy jsou druhem (dobré) nápodoby.

ii Na druhou stranu je třeba uvést, že Sókratés v Politeii (392d-394c) hovoří o třech druzích slovesného projevu, výkladem o nichž chce završit pojednání o tom, co je třeba mluvit a jak je to třeba mluvit: prostý, napodobující a smíšený. Jako př́klady jednotlivých projevů udává pro sloh prostý dithyrambickou poezii, pro sloh napodobující tragédii a komedii, pro sloh smíšený epickou poezii. Nejhůře je hodnocen sloh napodobující, čili tragédie a komedie.
} 
disciplinovaný, rozvážný, statečný a uměřený. Napodobovat se má tedy takové jednání, které slouží především ke kultivaci iracionálních stránek duše. V tomto bodě se stýká Platónova sociální psychologie, pedagogika a politické myšlení, které mají podobu kritiky demokracie a jejich institucí včetně divadla v jeho tragické i komické podobě.

Tragický básník se nesnaží a ani nemůže působit na rozumnou stránku duše, protože chce-li uspět, musí potěšit dav (Rep. 605-607). Usiluje tedy o jediné, aby vzbudil libost u diváků a je svým způsobem otrokem hlediště, které je tyranem (Gorgias 502b). To jej spojuje s řečníky na sněmu a soudech, jak říká Sókratés (Gorgias 502c), kteří rovněž mluví k davu a rovněž se mu snaží zavděčit. Jediný rozdíl je v tom, že tragický básník mluví k publiku rytmicky, v metru a projev provází hudba. Kdybychom však toto vše z řeči sňali, zůstane holá řeč. Proto Sókratés označuje tragické básnictví za druh sněmovní řeči a kritika tragického básnictví se tak stává součástí kritiky rétoriky. Lid je tedy pánem nejen na sněmu a na soudě, ale $\mathrm{i}$ v divadle. V Zákonech je pro tento vztah užito pojmenování theatokracie (701a). Tato theatokracie je prŕíčinou toho, proč není možné publikum vychovávat, protože kdykoli se pronese něco kritického na jeho adresu nebo něco, co vzbuzuje nelibost, zahrnuje básníka pískotem a jinými projevy nesouhlasu. U publika tedy nelze očekávat a nelze u 
něj podporovat stud, respekt $\mathrm{k}$ mínění moudřejších a lepších lidí a bázeň. Od publika naopak můžeme očekávat

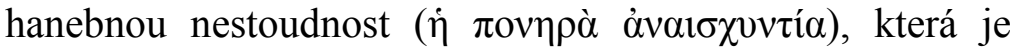

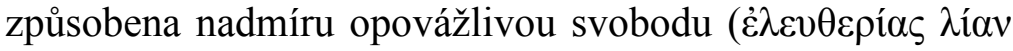
$\dot{\alpha} \pi \circ \tau \varepsilon \tau \mathrm{o} \lambda \mu \eta \mu \varepsilon \dot{v} \eta \varsigma)^{\mathrm{i}}$. Tragické drama je tedy vzhledem $\mathrm{k}$ tomu, že je demokratickou masovou institucí jako sněm a soudy, odsouzeno být otrokem vkusu a libosti většiny, proto se z výchovného prostředku stává nejvítanějším zdrojem zábavy a lichotivé rétoriky ${ }^{\mathrm{ii}}$. Vzhledem $\mathrm{k}$ tomu, co jsme řekli výše o katartické výchově, je možné konstatovat, že tragické divadlo je neprítelem filosofie, protože strhává duše lidí do neřádnosti, nevědomosti a podřizuje se jejich žádostivé složce. Ještě přesnější však je hodnocení, že problém nespočívá $\mathrm{v}$ tragické poezii samé, ale v demokratické společnosti, ve které je tragické divadlo provozováno. Protiklad tragické poezie jako demokratické masové instituce a filosofie je tedy protikladem katartické výchovy a rétoriky, racionality (elenchu) a iracionality (přemlouvání). Vzhledem $\mathrm{k}$ Platónovým názorům na úlohu filosofie a filosofa ve společnosti je rovněž protikladem elity a masy, veřejného a soukromého. Katartická výchova

\footnotetext{
${ }^{\text {i }}$ Leg. 701b. Pro přesnost je třeba uvést, že Platón na tomto místě Zákonu nehovoří specificky o tragické tvorbě, ale obecně o zákonech týkajících se múzického umění, které ale platí i pro tragické divadlo.

ii V dialogu Minos se tragické poezii dostává následujících prŕivlastků: pro lid nejpřitažlivější a nejpřesvědčivější.
} 
totiž není přístupná širokému publiku či veřejnosti. Je to individuální, a proto soukromá, výchova. ${ }^{i}$ Filosofie je v politickém prostředí demokracie nemožná. Jak ukazuje Schofield, Platón v dialozích Gorgias a Politeia reformuloval sókratovský pohled na úlohu filosofie v demokratických Athénách. ${ }^{\text {ii }}$ Zatímco Sókratés Apologie chápe sama sebe jako člověka, který filosofií prokazuje největší dobro svým spoluobčanům (36c-d) a svou smrtí dokazuje, že filosofie pro něj není možná mimo demokratické Athény, Sókratés Politeie (496a-e) je člověk, který dává přednost životu v soukromí a s pohrdáním sleduje nezákonné jednání svých spoluobčanů, protože si uvědomuje, že jeho činnost by na ně neměla žádný vliv, chovají se totiž jako šílenci a divoká zvěř, a sobě by tím také neprospěl.

\section{b) Aristotelés o tragédii}

Aristotelovo dílo je možné vnímat v mnoha ohledech jako kritiku Platóna a nejinak tomu je, jak uvidíme, i v otázce výchovné funkce tragické poezie. Přesto Aristotelés sdílí s Platónem celou řadu teoretických

\footnotetext{
i Salkever (1990:284) ve svém článku hovoří o Platónově a Aristotelově obecné preferenci soukromé výchovy před veřejnou či masovou a dodává, že přestože tragédie uživá podobně jako filosofie (Platón) obrazů a mýtů, odmítá jí Platón, protože je přesvědčen o principiální nevzdělavatelnosti lidu.

ii M. Schofield, c.d.,str. 19-30.
} 
východisek. Stejně jako Platón předpokládá, že většina lidí dává přednost neuspořádanému životu před ctnostným životem (Pol.1319b31-34, EN 1168b15-20). Ve shodě s Platónem považuje tento sklon za něco, co obecně souvisí s lidskou biologickou přirozeností - všichni živočichové přirozeně touží po slasti, jež spočívá v uspokojování potřeb a přirozených žádostí, bez ní není možné přežít. ${ }^{i}$ Rovněž sdílí s Platónem předsudek vztahující se k nižním třídám.

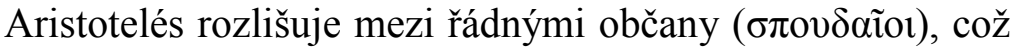
jsou ti, kdo usilují o ctnostný život, a špatnými občany

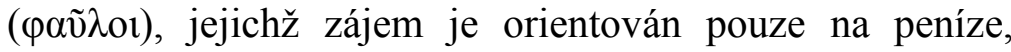
pocty a tělesná potěšení, což Aristotelés stejně jako Platón označuje termínem pleonexia (EN 1168b15-20). ${ }^{\text {ii }}$ Proti pleonexii v její trojí podobě lze bojovat zákony, výchovou a filosofíi (Pol.1267b). Dle Platóna jsou lidové masy rezistentní vůči všem těmto možnostem, zatímco elita nikoli. Aristotelés se s tímto názorem úplně neztotožňuje a na určitých místech Politiky je naopak kritický k elitě. Př́íkladem je čtvrtá kniha (1297a7-13), kde v rámci obhajoby smíšené ústavy přichází s tezí, že pleonexie lidu podvrací ústavu méně než pleonexie boháčů, a proto je

\footnotetext{
${ }^{\mathrm{i}} \mathrm{O}$ duši 2.3 414a30-414b15.

ii Detailní analýzu eticko-normativních přístupů k pleonexii lze nalézt u Ryana Balota (2001)
} 
nemoudré prosazovat aristokratickou ústavu. ${ }^{\mathrm{i}}$ Zásadní nesouhlas s Platónem panuje v pohledu na lid jakožto kolektivně se rozhodující politické těleso a kvalitu jeho rozhodování. V diskusi o mocenských nárocích a suverenitě se Aristotelés zabývá otázkou, zda má mít vůdčí úlohu ve státě množství ( $\tau$ ò $\pi \lambda \tilde{\eta} \theta 0 \varsigma$ ) nebo několik výjimečných jedinců ( argumentuje, že i když jednotliví občané nemusí být

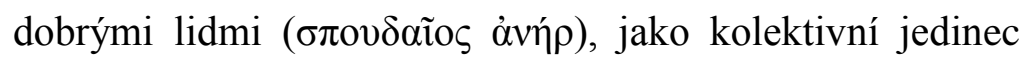
jsou dobří, disponují morálními kvalitami a vynikající usuzovací schopností, která převyšuje schopnosti výtečného muže. $Z$ toho důvodu je také občanský kolektiv lepším posuzovatelem hudby a poezie než jedinec. ${ }^{i i}$ Síla kolektivní usuzovací schopnosti tedy pokrývá jak oblast politickou, tak oblast uměleckou. Na druhou stranu je Aristotelés opatrný a svou argumentaci lehce relativizuje, když tvrdí, že není jasné, zda to platí o každém občanském tělese. Musíme se tedy podívat, pro která občanská tělesa toto platí a pro jaká neplatí a zda se tento úsudek netýká také demokratických obcí. Zcela jistě neplatí úvahy o kolektivní moudrosti pro oligarchické občanské společenství, které je charakterizováno krajní pleonexií. Rovněž demokratické

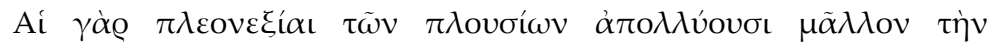

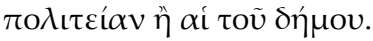

ii Politika III. 1281b-1282b.
} 
občanské společenství není hodnoceno př́lišs vysoko a za nejlepší zř́zení $v$ rámci daných možností považuje Aristotelés politeiu ${ }^{\mathrm{ii}}$; přesto se mu zdá určitý druh demokracie nejméně špatnou formou zrrízení. Nejlepším ze špatných zř́zení a druhů demokracie je rolnická demokracie, protože její občanskou základnu tvoří z větší části lidé skromného majetku, kteří musejí intenzivně pracovat a nemohu tak dát průchod touhám po vládě a zisku, které jsou vlastní většině lidí (Pol.1318b7-18). Kromě toho práce $\mathrm{v}$ zemědělství je činí otužilými, což je velmi dobré pro vojenskou službu. Nejhorší formou demokracie je ta, kde se všichni podílejí na vládě a kde se udílí občanství chudým a bez řádného občanského původu, aby takové množství převýšilo střední třídu a aristokraty. (Pol.1319b) V takovém zř́zení si každý může dělat, co chce, což má za následek mimořádnou volnost nejen mezi občany, ale i mezi otroky, ženami a dětmi, čímž se tento druh demokracie sbližuje s tyrannidou, protože jak občan, tak tyran se vyznačují naprostou libovůlí. V tomto bodě se Aristotelovy úvahy o občanském tělese špatné formy demokracie shodují s Platónovými úvahami o demokracii a

i Politika IV.2 1289a26-30.

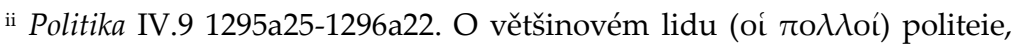
kterým jsou příslušníci střední vrstvy, se dá říci, že disponuje kolektivní moudrostí, nebot' je jakýmsi vzorem optimalizace demokratických procedur rozhodování a díky aplikaci proporční rovnosti eliminuje to, čeho se Aristotelés obává: přímé vládnutí všech. 
člověku demokracie v osmé knize Politei. ${ }^{\mathrm{i}}$ Ukázali jsme ve stručnosti, jaká kolektivní občanská tělesa lze pokládat za moudrá, a jaká nikoli. Položme si však otázku, která se zabývá tyranským snem každé lidské bytosti. Lze tento sen nějak kolektivně mírnit? Pokud většinový lid v podstatě přístupný filosofii a racionální argumentaci, není př́stupný něčemu jinému? Domnívám se, že Aristotelovy úvahy o tragédii se ubírají právě tímto směrem a současně opačným směrem než Platónovy. Vyjděme z Aristotelovy definice tragédie.

Aristotelés v Poetice definuje tragickou poezii

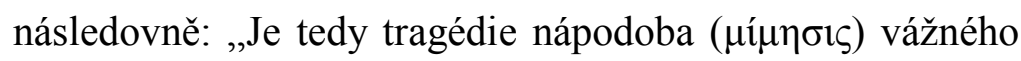

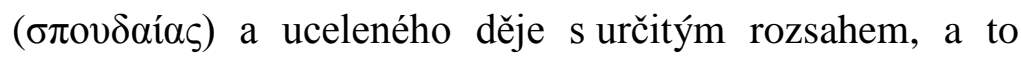
taková, při níž se užívá řeči zkrášlené v každém úseku př́slušnými prostředky zvlášt', děj se nevypraví, ale

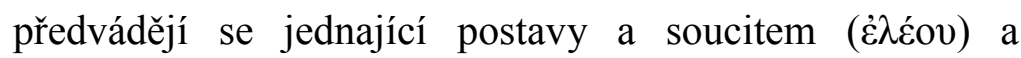

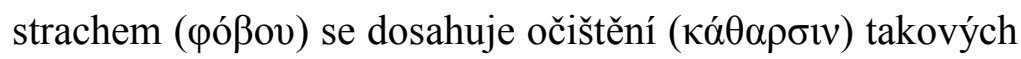
pocitů.“"(1449b23-28). ${ }^{\text {ii }}$

Aristotelova definice tragédie stejně jako následné pojednání se vždy zdály v jistém smyslu záhadné. ${ }^{\text {iii }}$ Zaprvé

i První výraz těchto názorů však najdeme v pseudo-Xenofóntově Ústavě Ústavě Athéňanů (I. 5, I. 10-12).

ii Přeložil Milan Mráz (Praha: OIKOYMENH 2008). Mrázův překlad jsem jsem však upravil a místo výrazu "zobrazení" jsem užil termínu „nápodoba“, abych zachoval odkaz na řecký termín mimésis.

iii Předně Aristotelés se vždy na úvod vypořádává s názory předchůdců.

V Poetice tomu tak není. Aristotelés je poměrně pečlivý, pokud jde o 
v Poetice nikde nepojednává o významu soucitu a strachu, ani o tom, co má na mysli oním očištěním. Dále dle Aristotela každé umění má nějaký cíl, existuje kvůli něčemu. Pojednání o tragédii v Poetice však obsahuje jen krátké vymezení cíle bez bližší specifikace. Aristotelés říká, že cílem tragédie je vzbudit požitek plynoucí ze soucitu a strachu (1453b10-13). V pasáži, kde si připravuje půdu pro výklad o př́iběhu jako duši tragédie, říká, že příběh je tím,

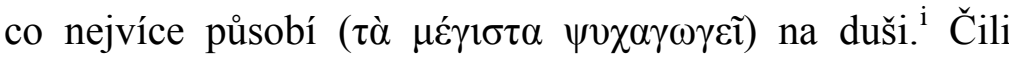
cílem je působení na duši diváka. $Z$ tohoto hlediska se tragédie sbližuje s rétorikou. Aristotelés podobně jako Platón pohlíží na tragickou poezii jako na svébytný druh rétoriky. Básník totiž musí užívat podobných postupů jako řečník, proto Aristotelés v Poetice odkazuje při pojednání o myšlenkové stránce a projevu na Rétoriku (1403a36). Mezi tragickým básníkem a rétorem je ale jeden rozdíl. $\mathrm{V}$ tragédii musí události působit zamýšleným dojmem i bez přednesu, zatímco rétor dosahuje účinku teprve tím, jak mluví. Kdyby tomu tak nebylo, nebyli bychom schopni zdůvodnit úlohu řečníka (1456a32-1456b6). Sblížení tragédie s rétorikou je zmíněno v Poetice ještě jednou, když Aristotelés pojednává o významu myšlenky neboli schopnosti mluvit $\mathrm{k}$ věci a odpovídajícím způsobem, což je úkol politické vědy a

definici termínů a jejich výklad, v Poetice ale výklad a definici základních termínů chybí.

i 1450 a33 
rétoriky. Starší básníci dle Aristotela nechávali své postavy mluvit jako politiky, zatímco současní jako rétory (1450b5). Přemlouvací schopnost, která je cílem tragédie, je do určité míry společná nejen pro rétoriku, ale i pro politickou vědu, protože jak tragédie, tak politická věda se zabývají otázkami dobrého a špatného jednání. Avšak politická věda je diskurzivní disciplína, zatímco tragédie podobně jako určitý druh rétoriky užívá př́kladů a obrazů.

Kdo nebo jaké publikum může být pohnuto tragédií? Na koho a jak má tragédie působit? Aristotelés se na rozdíl od Platóna nedomnívá, že existuje jediná a absolutní metoda výkladu a působení. V Metafyzice (2.3 995a1-15) hovoří o vztahu publika a charakteru výkladu. Někteří lidé přijímají jen argumentaci matematického charakteru, jiní ji nejsou schopni sledovat a dávají přednost výkladu s př́klady, jiní jsou zvyklí na príběhy. VRétorice Aristotelés uvádí, že posluchači rétoriky jsou lidé, kteří nejsou schopni najednou přehlédnout mnohost věcí a usuzovat z delší myšlenkové řady (1357a). Takových lidí je dle Aristotela většina. To přesto neznamená, že by nemohli být přivedeni $\mathrm{k}$ něčemu pravdivému nebo dobrému. Tím se dostáváme $\mathrm{k}$ výkladu o soucitu a strachu. Aristotelés o těchto emocích pojednává $\mathrm{v}$ Rétorice $\mathrm{v}$ rámci obsáhlého výkladu o vlivu citů na soudnost. ${ }^{i}$ Strach je dle Aristotela

${ }^{\mathrm{i}}$ II. 5 , II. 8 
druh nelibosti nebo zneklidnění, který vzniká z představy budoucího zla, jež působí záhubu nebo bolest. Strašné je všechno, co budí soucit a největší strach budí, když se dopustíme chyby, kterou nemůžeme napravit. Strach však necítí každý. Zdá se, že lidé, kteří žijí ve štastných poměrech, se nedomnívají, že by je mohlo postihnout nějaké trápení, a proto se $\mathrm{v}$ nich rodí zpupnost, pohrdavost a drzost. Strach také necítí lidé, kterým je vše jedno, protože se jim zdá, že už jejich stav nemůže být horší. Proto je strach spojen s nadějí na změnu poměrů, což nutně vede k tomu se o takové změně či nápravě poradit. Strach je tedy emoce, která racionalizuje jednání. Rovněž soucit je druhem bolesti nad zjevným zlem, jež hrozí zhoubou nebo bolestí a postihuje někoho, kdo si to nezaslouží a můžeme-li očekávat, že postihne nás nebo někoho z našich blízkých. Soucit nemají lidé naprosto bídní a nadmíru št'astní, hněvivé a smělé povahy. Naopak ideální skupinou jsou Ti, kteří mají ženy, děti, dále staří a vzdělaní lidé. Soucit je tedy svázán se strachem a podobně jako strach jej nelze hledat u dvou krajních skupin obyvatel.

$S$ výrazem katharsis $\mathrm{v}$ souvislosti $\mathrm{s}$ uměním či výchovou se u Aristotela setkáme kromě Poetiky pouze jednou, a to v Politice, kde pojednává o významu hudebního vzdělání, jež kromě výchovné a zábavné funkce může vést také ke katarzi (1341b39). Aristotelés slibuje, že 
se k výkladu tohoto termínu vrátí v pojednání o poezii. Tento návrat však nemáme dochovanýi. Staletí trvající bádání přineslo tři hlavní interpretace pojmu katharsis ${ }^{\mathrm{ii}}$ :

1. katarze označuje náboženské očištění (v tomto smyslu užito v Poetice 1455b)

2. katarzi je třeba chápat jako léčbu emočního nesouladu po vzoru hippokratovského lékařství (v tomto smyslu užito v Politice 1341a-1342a)

3. katarze označuje osvícení.

Ani jedna z interpretací pojmu katarze se však nezdá být přiléhavá pro definici tragédie. Žádná $\mathrm{z}$ těchto interpretací si totiž neklade otázku, u koho má dojít k očištění strachu a soucitu. Aristotelés sám paradoxně otázku charakteru

i Jak poznamenává Halliwell, tento odkaz se může vztahovat jednak ke ztracené druhé knize Poetiky, nebo k ranému dialogu O básnících, kde „mohl Aristotelés zavést pojem katarze, aby zamezil Platónovu obvinění, že vzbuzování emocí tragickou poezií zvyšuje náchylnost ke stejným emočním projevům v běžném životě." (Aristotle: Poetics. Harvard University Press 2005, str.18). Podobně uvažuje i Nussbaumová (2003: 718), když interpretuje Aristotela v tom smyslu, že dle jeho názoru "tragédie přispívá $\mathrm{k}$ lidskému sebepoznání právě tím, že zkoumá to, co je politováníhodné a co probouzí strach. A tento průzkum uskutečňuje Aristotelés tak, že nás vede $\mathrm{k}$ tomu, abychom reagovali právě těmito emocemi. Tyto emocionální reakce totiž samy o sobě svědčí o poznání a uznání pozemských podmínek pro naše úsilí o dosažení dobra."

ii Srovnej Bernays (1880), Else (1957: 224-232 a 423-447), Lucas (1968: 273290), Golden (1973: 473-479), Halliwell (1986: appendix 5), Salkever (1990:292), Rorty (1992:12-15), Lear (In Rorty 1992:315-340), Janko (In Rorty 1992:341-358), Nussbaumová (2003: 715-720). 
publika v Poetice nerozvádí. Přikláním se však k Salkeverovu názoru (1990:292), že při interpretaci pojmu katarze je třeba vzít $\mathrm{v}$ úvahu právě povahu publika tragédie. ${ }^{\mathrm{i}}$ tragédie. ${ }^{\mathrm{i}}$ Tragédie zcela jistě není určena publiku složenému z velmi zámožných a mocných lidí, kteří nejsou citliví, pokud jde o emoce strachu a soucitu, ani pro deklasované živly. ii Ideálním publikem tragédie je tedy většinové obyvatelstvo, které stojí mezi uvedenými

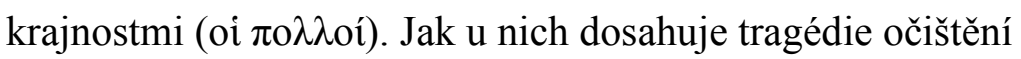
strachu a soucitu? Strach a soucit vzbuzují „hlavně události, kdy jedna vyplyne z druhé proti očekávání; tak totiž způsobí větší překvapení, než kdyby se staly samy od sebe a náhodou (1452a3-6).“ Rovněž osud libovolného hrdiny nevzbuzuje strach a soucit. Aristotelés říká, že hrdina musí být člověk, který je uprostřed mezi dvěma krajnostmi; nevyniká ani ctností a spravedlností, ani se nedostává do neštěstí pro svou hanebnou povahu, ale v důsledku nějakého pochybení ( $\dot{\alpha} \mu \alpha \rho \tau i ́ \alpha)$, a patří $\mathrm{k}$ lidem slavným a št’astným (1453a6-11). Co má však Aristotelés na mysli pochybením ( $\dot{\alpha} \mu \alpha \rho \tau i ́ \alpha)$ ? Zdálo by se, že je to obecně lidská omylnost spočívající v nevědomosti, ale jak upozorňuje

\footnotetext{
i Nesouhlasím však se Salkeverem v určení cílové skupiny jako lidu nejlepší demokracie. Jak jsem již řekl výše, nejadekvátnějším publikem by byl spíše lid politeie, teprve na druhém místě skupina, o které hovoří Salkever.

ii Viz výše o strachu a soucitu.
} 
Halliwell, není možné vyloučit ani skutky vášně a omezené provinění hrdiny. ${ }^{i}$ Dle Nussbaumové se pojem d $\mu \alpha \rho \tau i ́ \alpha$ týká týká mnoha různých forem pochybení, jež však nevyplývají z trvalé špatnosti charakteru hrdiny. ${ }^{\text {ii }}$ Lucas (1968: 302) považuje za podstatu $\dot{\alpha} \mu \alpha \rho \tau i ́ \alpha$ nevědomost, jež se snoubí $\mathrm{s}$ chybějícím špatným úmyslem, o čemž hovoří Aristotelés $\mathrm{v}$ Etice Nikomachově (1110b20-30) $)^{\mathrm{iii}}$. Co či jakou oblast důsledky této $\alpha \mu \alpha \rho \tau i ́ \alpha$ zasahují a vzbuzují tak strach a soucit? Jsou to „případy, kdy si působí utrpení příbuzní (

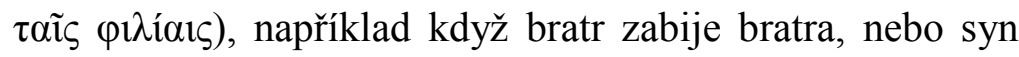
otce, nebo matka syna, anebo syn matku, nebo když se k tomu chystá nebo dělá něco podobného.“(1453b18-21). ${ }^{\text {iv }}$

\section{${ }^{i}$ Halliwell 2005:17}

ii Nussbaum (2001: 705-706).

iii Diskuse o významu a užití $\alpha \mu \alpha \varrho \tau i ́ \alpha$ trvá od poloviny 19. století. Mezníky v této diskusi jsou díla následujících autorů: Hey (1928:1-18, 137-164), Glanville (1949: 47-56), Ostwald (1958: 93-108), Adkins, (1966:78-102), Bremer (1969), Dawe (1968: 89-123), Stinton (1975: 221-254) a zvláště Schütrumpf (1989: 137-156). Schütrumpf ukazuje, jak je Aristotelovo chápání $\alpha \dot{\alpha} \alpha \varrho \tau i ́ \alpha$ zakotveno v tradici právních úvah o vině a odpoverdnosti: „The theory developed by Aristotle in Ethics for the accountability of agents for their actions can be traced to legal concepts, but it illustrates borderline cases of such actions from tragedy as well. On the other hand, the wording in Poetics ch.13 in its reduction to the contrast $\kappa \alpha \kappa i ́ \alpha-\alpha \mu \alpha \varrho \tau i ́ \alpha$ betrays rather the influence of court speeches and rhetorical theory. In this respect the Poetics shows its affinity to Rhetoric, which deals with the legal question of accountibility for one's action. The same problem was raised in the tragedies, which themselves presuposed the views of the issue expressed in Athenian law." (1989:155-156)

${ }^{\text {iv }}$ Přeložil Milan Mráz (Praha: OIKOYMENH 2008). 
Pojem $\varphi \imath \lambda i ́ \alpha$ je jednou z ústředních Aristotelových etických

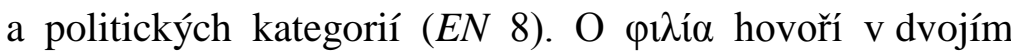
smyslu: rodinná či pokrevní pouta, a náklonnost či soudržnost mezi občany ( $E N$ 1161b). Přátelství a láska je jak základem rodiny, tak základem občanského společenství (EN 1155a23-28; Pol. 2.1262b1-20) a je rovněž nutnou podmínkou št'astného a smysluplného života ( $E N$ 1151a5). Vztah mezi těmito dvěma druhy pout je takový, že př́buzenská pouta jsou jedním ze základů občanského společenství. Děj, který vzbuzuje strach a soucit tím, že zasahuje rodinnou $\varphi \imath \lambda i ́ \alpha$, zasahuje nejsilnější citové pouto a je podstatou tragického umění. Děj tragédie teoreticky může oslovit každého posluchače, ale nejpravděpodobněji osloví většinové publikum, řadové občany s jejich rodinami.

V čem tedy spočívá didaktická funkce tragédie dle Aristotela? Nespočívá v napomínání, učení se nějakým pravidlům nebo vyvozování něčeho z nějakých předpokladů. Výchovná funkce tragédie spočívá v očištění emocí, které občany činí racionálnějšími a citlivějšími a působí na jejich emoce tak, aby jednali spíše dobře než špatně. Prostředky této emoční očisty jsou vzhledem k publiku voleny adekvátně, protože chápání událostí, které zničí rodinná či př́buzenská pouta, je narozdíl od filosofického výkonu a hledání schopna většina lidí. Z tohoto hlediska je tragická poezie pro určité občanské 
společenství ideálním výchovným prostředkem. Pokud je tato interpretace Aristotela správná, pak je rehabilitována tragická poezie jako $\tau \dot{\varepsilon} \chi v \eta$ a tragická katarze je co do své funkce neracionální protiváhou Platónově kathartické paideii, jež spočívá v elenchu. ${ }^{\mathrm{i}}$ Aristotelův postoj je tedy zřetelně protikladný Platónově kritice tragédie jakožto emočního zjitřování, jež ve svém důsledku vede ke změkčilosti. Koncepci katharsis tak můžeme chápat jako odpověd' na Platónovu kritiku, což podporuje i skutečnost, že jak v Poetice, tak v Politice a Rétorice nacházíme na klíčových místech odkaz na Platónovu Politeiu. ${ }^{\text {ii }}$

\footnotetext{
${ }^{i}$ Nussbaum (2003:718-719) rovněž vnímá tento kontrast, ale nevyjadřuje se takto explicitně.

ii Kritický vztah Aristotela k Platónovi je podtržen v závěru druhé knihy Poetiky, kde Aristotelés provádí srovnání mezi epikou a tragickým básnictvím. Viděli jsme, že v Politei Platónův Sókratés při diskusi o výchově strážců zřetelně preferoval epiku před tragickou poezií. Naproti tomu Aristotelés v závěru Poetiky (1462b11-15) uvádí důvody, které favorizují tragické drama před epikou: tragédie disponuje vším, co náleží epice, je působivá jak při pouhém čtení, tak při předvádění, zobrazení v ní dosahuje svého cíle při menším rozsahu skladby, tragické zobrazení je jednotnější než epické, což je zřejmé z toho, že z jednoho eposu je možné vytvořit více tragédií. Rozdíl je však v tom, že Sókratés uvádí důvody etické a psychologické, zatímco Aristotelés moderně řečeno literárněvědné. Proti názoru, že jde o otevřenou polemiku Aristotela s Platónem a že je možné to vyvodit - kromě jiného z definice tragédie v Poetice, se staví Nehamas (In Rorty 1992:293).
} 


\section{Závěr}

Platón tragédii zavrhl jako masovou demokratickou instituci pokřivenou tyranskými sklony publika a jako element nepřátelský filosofii, racionalitě a pokusům o kultivaci nerozumných stránek duše. Platón byl přesvědčen o nemožnosti veřejné výchovy a $\mathrm{v}$ tragické poezii viděl antivýchovný prostředek, který posiluje demokratické opojení svobodou a živí v člověku tyranské sklony. Řečeno obecně demokratická masová instituce podporuje demokratické smýšlení, což dle Platóna činí jakýkoli pokus o zlepšení nemožným. Rovněž u Aristotela najdeme zmínku o tyranských sklonech publika a př́padech neblahého vlivu špatného vkusu na tragické básníky ${ }^{i}$, avšak Aristotela to nevede ke generalizaci ohledně tyranie publika, schopnosti úsudku publika nebo obecně řečeno kolektivního občanského tělesa, a tedy ani $\mathrm{k}$ následnému paušálnímu odsouzení tragické poezie a jejích výchovných možností. Nevede ho to ani ke zpochybnění tohoto druhu básnictví

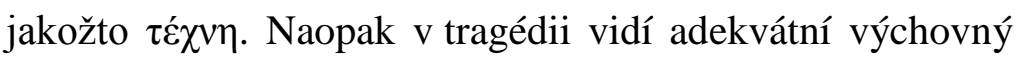
prostředek většiny určité občanské společnosti, která sice

\footnotetext{
i Poetika 1453a. Tato útržkovitá kritika v Poetice je podpořena pasáží v Rétorice (III. 1403b), kde se hovoří o přesvědčivosti v souvislosti $\mathrm{s}$ charakterem přednesu. Aristotelés si v této pasáži stěžuje na pokleslost tehdejšího tragického divadla a politické scény. Tato kritika se však netýká možností tragédie jako takové.
} 


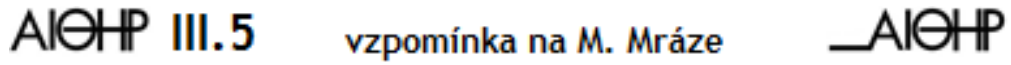

není schopna postupovat analyticky precizně, ale neznamená to, že nemůže nahlédnout nic hodnotného a že tyto náhledy na ni nemají blahý vliv. Péče o tyto blahodárné emoce totiž může způsobit, že občané budou inklinovat spíše k dobrému než ke špatnému jednání. Aristotelés by se však pravděpodobně shodl s Platónem na tom, že občanské těleso radikální demokracie, tj. té, které byl očitým svědkem, není takovéto kultivace schopno a lze vážně pochybovat i o jeho kolektivní moudrosti 


\section{Literatura}

Adkins, A. W. H. (1966), Aristotle and the Best Kind of Tragedy. Classical Quarterly 16, str. 78-102.

Balot, R. (2001). Greed and Injustice in Classical Athens. Princeton Princeton University Press.

Bernays, J. (1880). Zwei Abhandlungen über die aristotelische Theorie des Drama. Berlin.

Bremer, J. M. (1969). Hamartia: tragic error in the Poetics of Aristotle and in Greek Tragedy. Amsterdam.

Canfora, L. (1994). Storia della letteratura Graeca. Roma: Laterza.

Dawe, R. D. (1968). Some Reflection on at and hamartia. Harvard Studies in Classical Philology 72, str. 89-123.

Else, G. F. (1957). Aristotle's Poetics: The Argument. Cambridge (Mass.)

Glanville I. M. (1949). Tragic Error. Classical Quarterly 43, str. 47-56.

Golden, L. (1973). The Purgation Theory of Catharsis. The Journal of Aesthetics and Art Criticism, Vol. 31, No. 4.

Goldhill, S. (1990). The Great Dionysia and Civic Ideology. In: Winkler, J. J. \& Zeitlin, F. I., Nothing to do with Dionysos?: Athenian drama in its social context.

Goldhill, S. (2000). Athenian Drama and Political Thought. In: Rowe, Ch. \& Schofield, M., Cambridge History of Greek and Roman Political Thought. Cambridge: Cambridge University Press.

Halliwell, S. (1986). Aristotle's Poetics. London: Duckworth.

Halliwell, S. (2005). Introduction. In: Aristotle, Poetics. Cambridge: Harvard University Press.

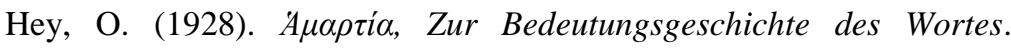
Philologus 83, str. 1-18 a 137-164.

Kosman, A. (1992). Drama as the Mimesis of Praxis. In: Rorty, A. O., Aristotle's Poetics. Princeton: Princeton University Press, str. 51-72. 
Lucas, D. W. (1968). Aristotle Poetics. Oxford: Clarendon Press.

Meier, Ch. (1993). The political art of Greek tragedy. Oxford: Polity Press.

Nehamas, A. (1992). Pity and Fear in the Rhetoric and the Poetics. In: Rorty, A. O., Aristotle's Poetics. Princeton: Princeton University Press, str. 290-310.

Nussbaum, M.C. (2001). The Fragility of Goodness: Luck and Ethics in Greek Tragedy and Philosophy. Cambridge.(Český překlad Křehkost dobra. Praha: OIKOYMENH 2003)

Ober, J. (1998). Political dissent in democratic Athens: intellectual critics of popular rule. Princeton: Princeton University Press 1998.

Ostwald, M. (1958). Aristotle on Hamartia and Sophocles'Oedipus Tyrannos. Festschrift Ernst Kapp. Hamburg, str. 93-108.

Rorty, A. O. (1992). Aristotle's Poetics. Princeton: Princeton University Press.

Salkever, S. (1990). Tragedy and the Education of the Dèmos. In: Euben, P., Greek Tragedy and Political Theory, 274-304. Berkeley \& London: California University Press.

Schofield, M. (2006). Plato: The Political Philosophy. Oxford University Press.

Schütrumpf, E. (1989). Traditional Elements in the Concept of Hamartia in Aristotle's Poetics. Harvard Studies in Classical Philology, vol. 92, str. 137-156.

Stinton, T. C. (1975). Hamartia in Aristotle and Greek Tragedy. Classical Quaterly 25, str. 221-254. 